\title{
Potential of dyes as draw solutions in forward osmosis for the South African textile industry
}

\author{
Marshall Sheldon'*, Estella Zandile Jingxi', Debbie De Jager', Robyn Augustine', Jasmina Korenak², \\ C Helix-Nielsen ${ }^{2,3}$ and Irena Petrinic ${ }^{2}$ \\ ${ }^{1}$ Cape Peninsula University of Technology, Department of Chemical Engineering, P.O. Box 652, Cape Town, 8000, South Africa \\ 'University of Maribor, Faculty of Chemistry and Chemical Engineering, Smetanova ulica 17, SI-2000 Maribor, Slovenia \\ ${ }^{3}$ Technical University of Denmark, Department of Environmental Engineering, Miljøvej 113, 2800 Kgs. Lyngby, Denmark
}

\begin{abstract}
The textile industry produces large volumes of wastewater that requires appropriate treatment before being released into the environment. Research globally has focused on advanced desalination technologies to augment the limited freshwater resources. Forward osmosis (FO) technology has gained substantial interest as a possible lower-energy desalination technology. However, challenges such as the availability of effective draw solutions (DS) have limited its implementation. This study evaluated alternative feed water resources and assessed the potential of dye solutions as DS. The aim is to dilute a concentrated dye DS to a target concentration for direct dye-batch use, thereby reclaiming water resources. The measured osmotic pressure (OP) of the alternative feed solutions (synthetic brackish water; syntethic seawater; seawater from the Atlantic and Indian Oceans; and wastewater from two textile factories) were 414, 2 761, 2580, $2614 ; 1716$ and $7822 \mathrm{kPa}$, respectively. Three basic dyes (Maxilon Turquoise, Red and Blue) and three reactive dyes (Carmine, Olive Green and Black) were selected based on common use in the South African textile industry. The dye samples were prepared without and with salt at different concentrations and different dye-to-salt mass ratios ranging from 1:10 to 1:60. The OP trends for the basic dyes followed Blue $>>$ Red $>$ Turquoise and for the reactive dyes Black $>>$ Olive $>$ Carmine. The overall OP trend was Black $>$ Olive $>$ Carmine $>$ Blue $>$ Red $>$ Turquoise. The OP at different dye concentrations and different dye-to-salt ratios was mostly influenced by the dye chemistry and molecular weight $(\mathrm{Mw})$ rather than the type of dye, i.e., reactive vs basic.The OP trend for the dye-to-salt ratios was 1:60>1:50>1:40>1:30>1:20>1:10. For both the basic and reactive dyes a linear relationship exists between OP and dye concentration; as well as between OP and Mw. The dye DS exhibited larger OP compared to that of the FS evaluated, thus rendering them suitable DS.
\end{abstract}

Keywords: draw solution; dyes; feed solution; forward osmosis; osmotic pressure; textile industry; textile wastewater

\section{INTRODUCTION}

The South African (SA) population has grown from 36 million in 1990 to an estimated 55 million in 2016, according to the latest census. SA's water and energy resources are under immense pressure due to its growing population, expanding economy and changing rainfall patterns (Von Bormann and Gulati, 2014). It has been predicted that SA will suffer serious water shortages by 2020 (Fioramonti, 2015). The Western Cape is currently experiencing one of its worst droughts in decades (with Level $6 \mathrm{~b}$ water restrictions from 1 February 2018) and the entire SA previously experienced immense load shedding during 2015 due to energy shortages. It has been reported that SA is already using $98 \%$ of its available water supply and $40 \%$ of its wastewater treatment is in a critical state (Fioramonti, 2015). The mismatch between water supply and water demand; energy supply and energy demand; the deteriorating infrastructure; loss of essential skills; deteriorating educational pipeline; the deterioration in the quality of water and energy shortages are all potential threats and key concerns. Thus, there is a strong demand for low-energy and low-cost water treatment methods. The growing awareness of water scarcity and energy shortages in SA has sparked a renewed interest in finding suitable and sustainable solutions.

\footnotetext{
* To whom all correspondence should be addressed.

面 +27 (21) 9596757

e-mail: sheldonm@cput.ac.za

Received 17 May 2017; accepted in revised form 27 March 2018
}

Global research has so far mostly focused on advanced technologies, such as desalination, to augment the limited freshwater resources. Increasingly the preferred seawater desalination method is the pressure-driven reverse osmosis (RO) membrane technology (Cohen-Tanugi et al., 2014), which accounts for about $59 \%$ of total seawater desalination plant capacity installed over the past 20 years (Desaldata, 2014). However, desalination technologies such as RO are still energy intensive (McGovern, 2014; Phuntsho, 2012; McGinnies and Elimelech, 2008; Semiat, 2008). Due to the growing global water scarcity; rising energy demand; rising energy cost; and negative environmental impacts, osmotically driven processes such as foward osmosis (FO) have gained renewed interest. FO technology could play a major role in solving the water scarcity and energy issues through alternative water sources such as saline water sources and wastewater reclamation (Sing et al., 2018; Hey et al., 2017; Hey et al., 2016a; Hey et al., 2016b; Phuntsho et al., 2012). If the performance evaluation of this technology is positive, the impact of this technology would be significant for a droughtstricken country like SA, where saline water is abundant in the form of seawater along the coastal areas and brackish groundwater in the inland areas.

\section{Forward osmosis (FO)}

FO was first developed in 1968 by Popper et al. but did not really advance until recently due to the lack of suitable semipermeable FO membranes and effective draw solutions (DS). Since then FO has shown good performance in a variety of 
applications, such as in concentrating nutrient-rich drinks (Garcia-Castello et al., 2009; Yang et al., 2009; Cath et al., 2006), and water and wastewater treatment and purification (Korenak et al., 2017; Achilli et al., 2009; Cornelissen et al., 2008; Shannon et al., 2008); it is also attracting attention as a potential technology to augment water supplies using seawater/brackish water desalination (Choi et al., 2009; Cath et al., 2006) and wastewater (Cartinella et al., 2006; Cath et al., 2005).

FO is attracting more interest in novel areas where separation and recovery of the draw solution (DS) is not necessary (McGovern, 2014; Phuntsho et al., 2014; Jung, 2013; Phuntsho 2012; Phuntsho et al., 2011). Some of the apparent advantages are that (i) by virtue of being an osmotically driven process and not a hydraulic pressure process, the propensity for fouling is lower and physically reversible (Shaffer et al., 2015; Phuntsho, 2012; Achilli et al., 2010; Mi and Elimelech, 2010; Lay et al., 2010; Tang et al., 2010; Choi et al., 2009; McGinnies and Elimelech, 2008; McGinnies and Elimilech, 2007); (ii) higher fluxes with recent developments in FO fabrication of thin film composites (TFC), carbon nanotube (CNT) and biomimetic membranes that provide lower concentration polarisation (Shaffer et al., 2015; Tang et al., 2015; Zhao et al., 2012a; Zhao et al., 2012b; Zhao et al., 2013; Wang et al., 2010; Yip et al., 2010; Gethard et al., 2011; Schnorr and Swager, 2011); and (iii) where the separation and recovery of the DS after desalination is irrelevant this technology offers a significant advantage over other desalination technologies such as RO (Phuntsho et al., 2012; Phuntsho et al., 2011). However, FO is still limited due to challenges related to water flux; reverse solute flux; lack of suitable FO membranes; fouling for high flux membranes; concentration polarisation; the identification of alternative non-conventional water sources as feed solutions (FS) and limited choices of draw solutes (Akther et al., 2015; Braekevelt et al., 2015; Shaffer et al., 2015; Chung et al., 2012). It is the latter challenge that this paper attempts to address.

\section{Draw solutions (DS)}

The driving force in the FO operation is generated by passing a concentrated solution across the permeate side of the membrane. The concentrated solution is commonly referred to as the draw solution (DS) (Korenak et al., 2017; Wang et al., 2012; McCutcheon and Elimelech, 2006). An ideal DS needs to fulfil requirements, such as, the generation of a high osmotic pressure (OP) greater than that of the feed solution (FS); the reverse flux of the draw solute must be minimal; regeneration of the DS has to be economical; and a DS is preferred to have a low molecular weight and low viscosity to reduce concentration polarisation (Korenak et al., 2017; Shaffer et al., 2015; Wang et al., 2012; Wicaksana et al., 2012; Ge et al., 2013; Klaysom et al., 2013; Achilli et al., 2010; McCutcheon and Elimelech, 2006; McCutcheon et al., 2005).

An overview summary of the many studies on DS that have been performed over the past few decades was published recently by Korenak et al. (2017). McGovern (2014) argued that FO research should refocus away from seawater desalination towards alternative applications where salinities are above those which RO cannot handle (i.e. applications that do not compete with RO), toward alternative novel applications where DS regeneration is not required, and toward finding alternative water sources (i.e. new novel water sources) that would result in significant reduction of freshwater usage.

\section{Application of FO in the SA textile industry}

In 2013 the clothing and textile, footwear and leather industry contributed around 8\% of SA's GDP. The domestic textile industry can be found mostly in the Western Cape and KwaZulu-Natal (both along the coast where abundant seawater is available), with only some activity occuring in Gauteng. According to the Textile Federation, the SA textile industry (including both textiles and apparel) is the $6^{\text {th }}$-largest manufacturing sector employer and the $11^{\text {th }}$-largest manufactured goods exporter. These industries are also usually one of the largest sectors in terms of value added in manufacturing, and for these reasons the SA government considers it to be a very important part of the economy (Truett and Truett, 2010). The quantity of water required for textile processing is large and varies between factories, depending on the fabrics produced and processed, and the water used is usually returned to the ecosystem without treatment.

As freshwater becomes scarcer, and treatment costs are escalating, the obvious means to solve the crisis are (i) to cut down the consumption of freshwater at all possible stages of processing, and (ii) reuse of wastewater in place of freshwater in certain operations. The latter option is gaining importance due to the dual advantages incurred, namely, the reduction in water consumption and lower quantities of wastewater generated. With the backing from top management, reuse of wastewater could result in large reductions of water consumption (Chougule and Sonaje, 2012). Developing water reclamation plants makes it possible to reuse water from textile finishing directly from the source of pollution. FO using a semi-permeable membrane may be a viable alternative to $\mathrm{RO}$ as a lower-cost and more environmentally friendly wastewater treatment, water reclamation or desalination technology.

The FO research at Cape Peninsula University of Technology (CPUT), SA, in collaboration with the University of Maribor, Slovenia, will work on the evaluation, understanding and development of the emerging FO technology within a SA context, more specifically within the textile industry, with the focus on significant reductions in the use of freshwater resources, increased water reclamation and reduced energy consumption. The research will aim to evaluate, understand and build knowledge around $\mathrm{FO}$ using alternative water sources for unique SA solutions. The focus of this paper is on evaluating the potential of (i) different dyes used in the clothing and textile industries in SA (specifically the Western Cape textile industry) as suitable draw solutions (DS), and (ii) alternative water resources as suitable feed solutions (FS). From the information presented in this paper, dye DS at specific concentrations and specific dye-to-salt ratios as well as selected alternative feed water solutions will be tested in a FO system with a dual purpose, i.e., to dilute a concentrated dye draw solution to a target concentration that can be used directly in the dyeing process, while at the same time reclaiming water from the alternative feed water resources. A follow-up article will report on the performance of selected dyes as draw solutes against selected feed water resources using a semi-permeable FO biomimetic membrane.

\section{METHODS}

\section{Feed solutions (FS)}

Deionized water (DI) was used as the control solution. Alternative FS that have been tested so far include (i) brackish 
water consisting of $5000 \mathrm{mg} / \mathrm{L} \mathrm{NaCl}$ (BW5); synthetic seawater consisting of $35000 \mathrm{mg} / \mathrm{L} \mathrm{NaCl}$ (SSW), actual seawater from the Atlantic (Clifton $4^{\text {th }}$ beach, Camps Bay and Seapoint beach) and Indian Oceans (Gordon's Bay, Strand Point A and Strand Point B) (AOSB and IOSB); as well as wastewater from two textile factories (TWW). With a large portion of the South African textile industry located in the Western Cape and KwaZulu-Natal (both coastal cities), seawater was evaluated as a feed water option for coastal industry applications and brackish water as an option for inland industries.

\section{Draw solutions - textile dye solutions}

The dyes that were tested as DS for the textile industry study are listed in Table 1. The three basic and three reactive dyes were identified from a list of commonly used dyes within the textile-dyeing industry and were sourced from Colorite (SA). Basic dyes, also known as cationic dyes, were selected as they are usually applied to wool, silk, cotton and acrylic fibres. Reactive dyes were chosen as they are used worldwide for the colorisation of cotton fabric due to their ease of applicability, cost, and high wet-fastness properties. Charge repulsion negatively affects reactive dyes, which are generally anionic when used with cellulosic fibres (such as cotton and linen), which when in water also have an anionic surface charge. An electrolyte in the form of salt, which surrounds the fabric, is normally added to overcome this repulsion and helps the dye to have a greater affinity for the fibre. The salt only aids the dyeing proces, and is discharged again in the textile wastewater (Rahman Bhuiyah et al., 2014; Zhang and Yang, 2003;

Houshyar and Amirshahi, 2002). The salt used in this study was $\mathrm{NaCl}$ sourced from Merck (SA).

Table 1 summarises the dyes' chemical formula, chemical structures and molecular weights $\left(\mathrm{M}_{\mathrm{w}}\right)$. The OP and performance of the dye DS were comparatively studied at different concentrations ranging between 0 and $0.2 \mathrm{~mol} / \mathrm{L}(\mathrm{M})$. These dyes were mixed with salt in various dye-to-salt mass ratios ranging from 1:10 to 1:60.

\section{Osmotic pressure (OP) measurements}

The osmotic pressure (OP) of the FS and DS were measured in duplicate using a Genotec Osmometer (Osmomat 3000; Scientific Group, Germany). The results reported are the averaged values. The measurements from the osmometer were in $\mathrm{mOsmol} / \mathrm{kg}$. The osmometer units were converted to OP (kPa) using Eq. 1 (Wijayasiri and McCombe, 2016):

\begin{tabular}{|c|c|c|c|c|c|c|}
\hline \multicolumn{7}{|c|}{$\begin{array}{c}\text { TABLE } 1 \\
\text { Basic and reactive dyes evaluated for osmotic pressure (OP) }\end{array}$} \\
\hline \multicolumn{2}{|l|}{ Dyes } & $\begin{array}{l}\text { Referred } \\
\text { to } \\
\text { in this } \\
\text { paper }\end{array}$ & $\begin{array}{l}\text { Molecular } \\
\text { weight } \\
\left(M_{w}\right) \\
(\mathrm{g} / \mathrm{mol})\end{array}$ & $\begin{array}{l}\text { Chemical } \\
\text { Formula }\end{array}$ & $\begin{array}{l}\text { Chemical } \\
\text { Structure }\end{array}$ & Reference \\
\hline \multirow{3}{*}{ Basic } & $\begin{array}{l}\text { Maxilon } \\
\text { Blue 5G }\end{array}$ & Turquoise & 359 & $\mathrm{C}_{20} \mathrm{H}_{26} \mathrm{ClN}_{3} \mathrm{O}$ & & $\begin{array}{l}\text { Dogan et al., } \\
2008\end{array}$ \\
\hline & $\begin{array}{l}\text { Maxilon } \\
\text { Red GRL }\end{array}$ & Red & 402 & $\mathrm{C}_{18} \mathrm{H}_{22} \mathrm{BrN}_{6}$ & & $\begin{array}{l}\text { El-Sayed et al., } \\
2014\end{array}$ \\
\hline & $\begin{array}{l}\text { Blue } 41 \\
\text { GRL }\end{array}$ & Blue & 482 & $\mathrm{C}_{20} \mathrm{H}_{26} \mathrm{~N}_{4} \mathrm{O}_{6} \mathrm{~S}_{2}$ & & $\begin{array}{l}\text { Aljeboree et al., } \\
2017\end{array}$ \\
\hline \multirow{3}{*}{ Reactive } & $\begin{array}{l}\text { Reactive } \\
\text { Black } 5\end{array}$ & Black & 991 & $\mathrm{C}_{26} \mathrm{H}_{21} \mathrm{~N}_{5} \mathrm{Na}_{4} \mathrm{O}_{19} \mathrm{~S}_{6}$ & & Han et al., 2016 \\
\hline & $\begin{array}{l}\text { Remazol } \\
\text { Red: }\end{array}$ & Carmine & 492 & $\mathrm{C}_{22} \mathrm{H}_{20} \mathrm{O}_{13}$ & & $\begin{array}{l}\text { ChemicalBook, } \\
2017\end{array}$ \\
\hline & $\begin{array}{l}\text { Levifix } \\
\text { Olive Ca }\end{array}$ & $\begin{array}{l}\text { Olive } \\
\text { Green }\end{array}$ & 585 & $\mathrm{C}_{20} \mathrm{H}_{17} \mathrm{~N}_{3} \mathrm{Na}_{2} \mathrm{O}_{9} \mathrm{~S}_{3}$ & To be confi & \\
\hline
\end{tabular}




$$
P V=n R T
$$

where $R=$ Universal gas constant $(8.314 \mathrm{~J} / \mathrm{mol} \cdot \mathrm{K}) ; n / V=$ osmolality (mOsmol/kg. $\left.\mathrm{H}_{2} \mathrm{O}\right) ; T=$ absolute temperature $(\mathrm{K})$

\section{Forward osmosis experimental setup}

Preliminary FO experiments were conducted to assess the performance of a selected dye as a draw solute using a bench-scale CFO42D FO cell (Sterlitech Corporation, USA). Two identical variable speed Watson Marlow 323S peristaltic pumps (Dune Engineering, South Africa) were used for the circulation of the feed solution (FS) and draw solution (DS) counter currently at a volumetric flow rate of $600 \mathrm{~mL} / \mathrm{min}$. Since there was no hydraulic pressure difference across the membrane; the driving force was the osmotic pressure gradient $(\triangle \mathrm{OP})$ between the FS and DS.

From the data presented, the Reactive Black 5 dye solution was selected to be used as draw solute at a 1:10 dye-to-salt mass ratio and an initial concentration of $0.02 \mathrm{M}$. The 1:10 dye-tosalt ratio was selected on the basis of a recipe received from a textile industry. The salt $(\mathrm{NaCl})$ was sourced from Merck (South Africa). The aim was the production of a Reactive Black dye solution diluted to a target concentration of $0.004 \mathrm{M}$. These target concentrations were based on dye recipes received from the textile industry.

Deionised water (DI) was used as a control FS. The experiments were conducted at room temperature $\left(22 \pm 0.5^{\circ} \mathrm{C}\right)$. The initial volume of the FS and DS was $2 \mathrm{~L}$ and $1 \mathrm{~L}$, respectively. During experimentation, the weight change of the FS was recorded manually using a Labex, WA606 mass balance (Labex, South Africa) at $1 \mathrm{~h}$ intervals. The osmotic pressure of the FS and DS was measured using a Gonotec Osmomat 3000 Osmometer (Scientific group, Germany). The control experiments were conducted in duplicate and were carried to osmotic equilibrium (OE) in order to evaluate the maximum feed water recovery rate.

A semi-permeable Aquaporin A/S biomimetic FO membrane (Aquaporin, Denmark) was used for the preliminary study. The membrane was placed in the FO orientation mode.
The feed water recovery rate, $R_{\mathrm{e}}(\%)$, is the amount of water permeated per unit time and was calculated using Eq. 1 (Han et al., 2016):

$$
R_{\mathrm{e}}=\frac{\Delta V}{V_{f, i}} \times 100 \%
$$

where $V_{\mathrm{f}, \mathrm{i}}$ is the initial volume (L) and $\Delta V$ is the change in volume of the feed (L).

\section{RESULTS AND DISCUSSION}

\section{Osmotic pressure (OP) of alternative feed solutions (FS)}

Table 2 provides the OP of possible alternative FS options available in SA. The synthetic seawater (SSW) with $35000 \mathrm{mg} / \mathrm{L} \mathrm{NaCl}$ generated an OP of $2761 \mathrm{kPa}$, while the OP for synthetic brackish water with $5000 \mathrm{mg} / \mathrm{L} \mathrm{NaCl}$ (BW5) generated an average OP of $414 \mathrm{kPa}$, due to its relatively lower salinity. The seawater collected from the Atlantic Ocean seaboard (AOSB), containing an average of $30400 \mathrm{mg} / \mathrm{L} \mathrm{NaCl}$, produced an average OP of $2580 \mathrm{kPa}$. The seawater collected from the Indian Ocean seaboard (IOSB), containing an average of $50292 \mathrm{mg} / \mathrm{L} \mathrm{NaCl}$, produced an average OP of $2613 \mathrm{kPa}$. The OP for SSW and BW5 obtained in this study was of the same order and magnitude as that reported in literature which was determined using software from OLI Stream Analyser 3.2 (OLI Systems Inc., Morris Plains, NJ, USA). The measured OP compared very well with OP reported in literature (Akther, et al., 2015; Phunthso, 2012; Phunthso et al., 2011), while the variations in the OP from literature compared to that measured in this study was attributed to the difference in analytical methods used and the composition of the solutions. The OP of textile wastewater (TWW) from two factories in the Western Cape (SA) was analysed. The TWW from Factory 1 and 2 were generated from processes using different dyes; production processes and dye recipes, resulting in significantly different

\begin{tabular}{|c|c|c|}
\hline \multicolumn{3}{|c|}{$\begin{array}{c}\text { TABLE } 2 \\
\text { Osmotic pressure (OP) of the alternative feed solutions (FS) evaluated }\end{array}$} \\
\hline Alternative feed solutions & $\begin{array}{l}\text { Measured } \\
\mathrm{OP}(\mathrm{kPa})\end{array}$ & Literature comparison \\
\hline Brackish water (BW5) $5000 \mathrm{mg} / \mathrm{L} \mathrm{NaCl}$ & 414 & $390 \mathrm{kPa}$ (Phunthso, 2012; Phunthso et al., 2011) \\
\hline Synthetic seawater (SSW) $35000 \mathrm{mg} / \mathrm{L} \mathrm{NaCl}$ & 2761 & $\begin{array}{l}26 \text { atm (converted to } 2600 \mathrm{kPa} \text { ) (Akther et al., 2015) } \\
28 \text { atm (converted to } 2800 \mathrm{kPa} \text { ) (Phuntsho et al., 2012) }\end{array}$ \\
\hline \multicolumn{3}{|l|}{ Seawater - Atlantic Ocean seaboard (AOSB) } \\
\hline Sample point 1: $29300 \mathrm{mg} / \mathrm{L} \mathrm{NaCl}$ & 2577 & \multirow{3}{*}{$\begin{array}{l}26 \mathrm{~atm} \text { (converted to } 2600 \mathrm{kPa} \text { ) (Akther et al., 2015) } \\
28 \text { atm (converted to } 2800 \mathrm{kPa} \text { ) (Phunthso et al., 2011; } \\
\text { Phunthso, 2012) }\end{array}$} \\
\hline Sample point 2: $30800 \mathrm{mg} / \mathrm{L} \mathrm{NaCl}$ & 2587 & \\
\hline Sample point 3: $31100 \mathrm{mg} / \mathrm{L} \mathrm{NaCl}$ & 2575 & \\
\hline \multicolumn{3}{|l|}{ Seawater - Indian Ocean seaboard (IOSB) } \\
\hline Sample point 1: $48048 \mathrm{mg} / \mathrm{L}$ & 2600 & \multirow{3}{*}{$\begin{array}{l}26 \text { atm (converted to } 2600 \mathrm{kPa} \text { ) (Akther et al., 2015) } \\
28 \text { atm (converted to } 2800 \mathrm{kPa} \text { ) (Phunthso, 2012; } \\
\text { Phunthso et al., 2011) }\end{array}$} \\
\hline Sample point 2: $50477 \mathrm{mg} / \mathrm{L} \mathrm{NaCl}$ & 2619 & \\
\hline Sample Point 3: $52352 \mathrm{mg} / \mathrm{L} \mathrm{NaCl}$ & 2621 & \\
\hline \multicolumn{3}{|l|}{ Textile wastewater (TWW) } \\
\hline Factory $1(20126 \mathrm{mg} / \mathrm{L} \mathrm{NaCl}+$ reactive dye $)$ & 1716 & No reported OP for TWW found in literature \\
\hline Factory 2 (composition not known) & 7822 & No reported OP for TWW found in literature \\
\hline
\end{tabular}
OP of 1716 and $7822 \mathrm{kPa}$, respectively. 


\section{Dye solutions as potential draw solutions (DS)}

Reactive and basic dyes were initially considered for selection as dye DS. Figure 1 illustrates the averaged measured OP for both the basic and reactive dyes as DS against the alternative FS that was evaluated for this part of the study. The effect of dye concentration on the OP was investigated firstly for dyes without any added salt. For the basic dyes the OP increased, with an increase in $\mathrm{M}_{\mathrm{w}}$ with the Blue dye $\left(\mathrm{M}_{\mathrm{w}}\right.$ of $\left.482 \mathrm{~g} / \mathrm{mol}\right)$ generating the highest $\mathrm{OP}$ of more than $8000 \mathrm{kPa}(80 \mathrm{~atm})$ at a concentration of $0.2 \mathrm{M}$, while Turqouise $\left(\mathrm{M}_{\mathrm{w}}\right.$ of $\left.395 \mathrm{~g} / \mathrm{mol}\right)$ only generated around $2000 \mathrm{kPa}(20 \mathrm{~atm})$ at $0.2 \mathrm{M}$. The results indicate a linear relationship between the basic dye concentration and OP. The effect of $\mathrm{M}_{\mathrm{w}}$ on measured OP is evident.

The dye DS should exhibit a greater OP than the target alternative FS (Phunthso, 2012). Comparing the OP of the dyes as possible DS to the OP of the possible FS it can be seen that the different dyes can only be considered as DS at initital concentrations where the $\mathrm{OP}$ is higher than that of the selected FS. For example, when Olive Green is used as the DS the only FS from those evaluated that can be used is BW5. If the Blue dye is used as the DS then BW5 and SW can be used as the FS.

Figure 1 also includes the OP of textile wastewater (TWW) as possible FS. This wastewater was generated during dyeing processes using Carmine (TWW-Carmine) and Olive Green (TWW-Olive) in the dyeing vats. If the textile wastewater (TWW-Olive) is used as the FS to reclaim water then the only dyes from those that were evaluated that can be used as the DS are Blue and Carmine with initial concentrations above $0.15 \mathrm{M}$ and $0.17 \mathrm{M}$, respectively.

Regardless of the application, any DS should exhibit inert, neutral and non-toxic properties (Klaysom et al., 2013; Wang et al., 2012; Wicaksana et al., 2012; McCutcheon and Elimelech, 2006). The DS should not react chemically with the feed solutes to form undesirable products that could hamper the osmotic process or the ultimate use of the product water. For the dye solutions evaluated in this study it was demonstrated that these dyes could be suitable DS as it complies with these DS requirements.

\section{Osmotic pressure (OP) of dyes combined with salt in different mass ratios}

Reactive dyes used in the dyeing of cotton fabric using conventional dyeing processes generally require large amounts of salt to help drive the dye onto the fabric. Therefore, further studies were conducted where these dyes were combined with salt in different dye-to-salt mass ratios. Figures 2 (a) to (f) represent the OP of dye stuffs at different concentrations combined with salt in different mass ratios. The effect of dye concentration and chemistry on the OP was investigated for dyes at different concentrations mixed with salt in different mass ratios. For both the basic and reactive dyes the OP increased with concentration and with increasing dye-to-salt ratio. The OP for the basic dyes followed the trend of Blue $>>$ Red $>$ Turquoise, which is the same order observed for the $M_{w}$ trend with Blue $(482 \mathrm{~g} / \mathrm{mol})>>$ Red $(402 \mathrm{~g} / \mathrm{mol})>$ Turquoise $(359 \mathrm{~g} / \mathrm{mol})$. The OP for the reactive dyes follows the trend Black $>$ Olive $>$ Carmine which is also the same order of the $\mathrm{M}_{\mathrm{w}}$ trend with Black $(991 \mathrm{~g} / \mathrm{mol})>>$ Olive $(585 \mathrm{~g} / \mathrm{mol})$ $>$ Carmine $(492 \mathrm{~g} / \mathrm{mol})$. The OP for the basic dye Blue $\left(\mathrm{M}_{\mathrm{w}}\right.$ : $482 \mathrm{~g} / \mathrm{mol}$ in Fig. $2 \mathrm{a}$ ) is similar to the OP range for the reactive dye Carmine ( $\mathrm{M}_{\mathrm{w}}: 492 \mathrm{~g} / \mathrm{mol}$ in Fig. 2d). The OP of the dyes combined in the salt ratios generated higher OP than the dyes with no salt in Fig. 1.

Figures 3 (a) to (f) represent the comparison of the OP of the different dye solutions at the same dye-to-salt ratio. For all the different dye-to-salt ratios the OP increases as the $\mathrm{M}_{\mathrm{w}}$ increases. The Black dye with the higher $\mathrm{M}_{\mathrm{w}}(991 \mathrm{~g} / \mathrm{mol})$ generated the highest OP compared to the Turquoise dye with lower $M_{w}(359 \mathrm{~g} / \mathrm{mol})$. The $M_{w}$ trend for each of the different dye-to-salt ratio graphs is Black $>$ Olive $>$ Carmine $>$ Blue $>$ Red $>$ Turquoise. The trend for the OP for the different dye-tosalt ratio is 1:60 >1:50 $>1: 40>1: 30>1: 20>1: 10$.

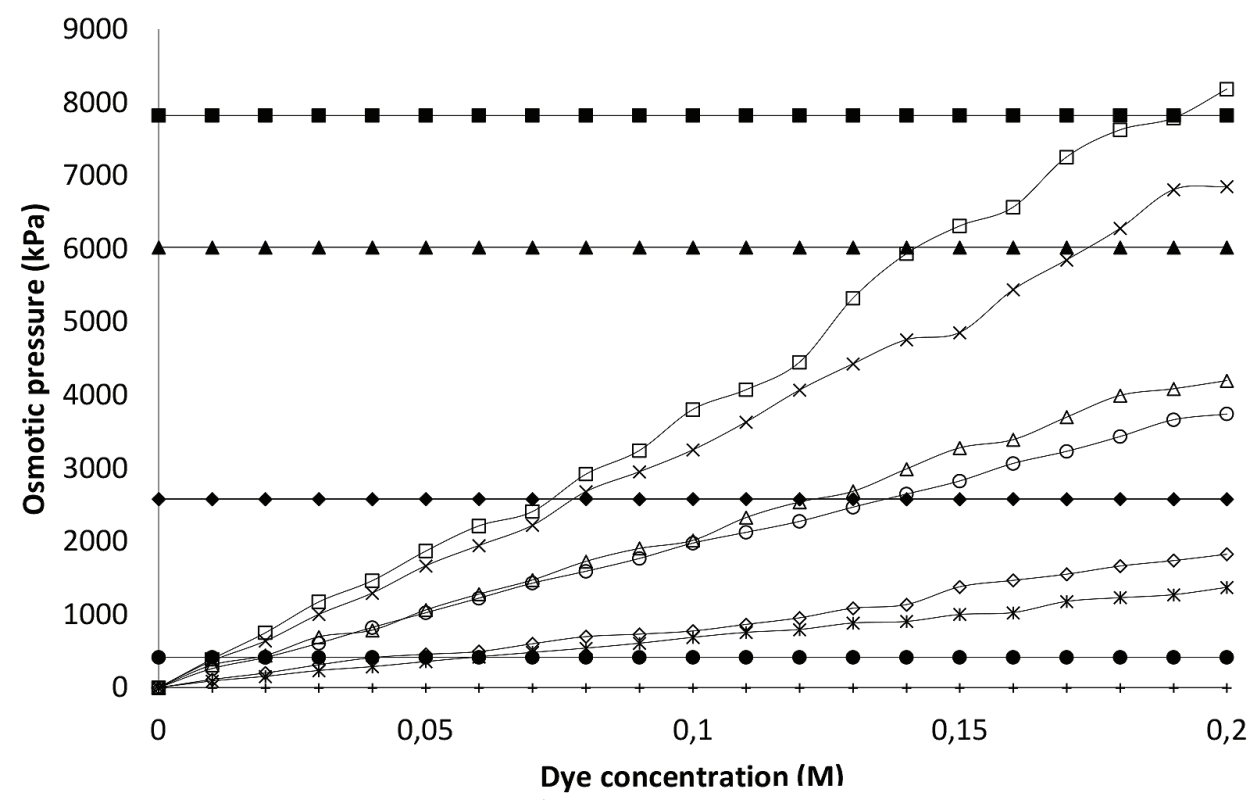

Basic dyes

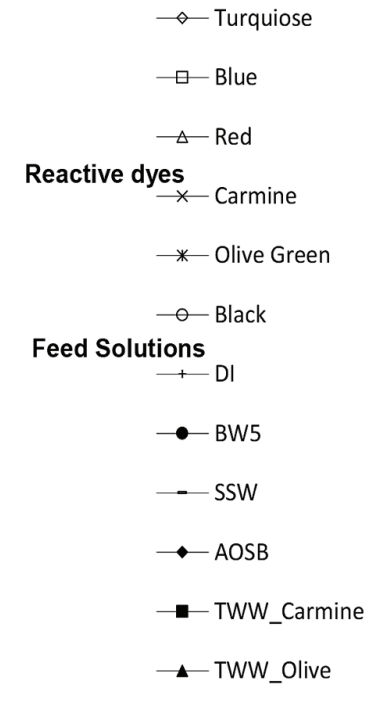

Figure 1

Osmotic pressure (OP) of selected dye solutions (with no salt added) at different concentrations vs OP of feed solutions (FS) 


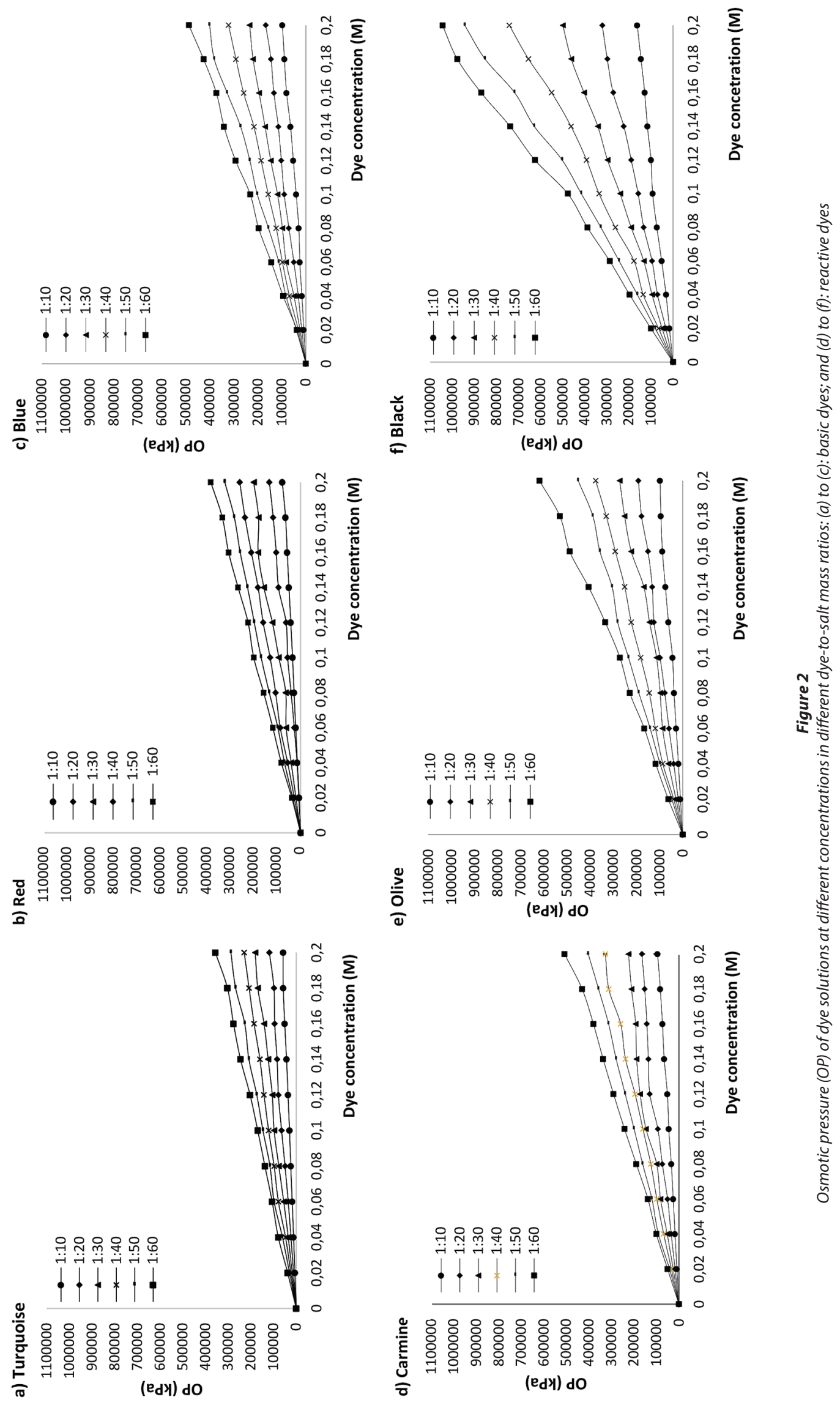



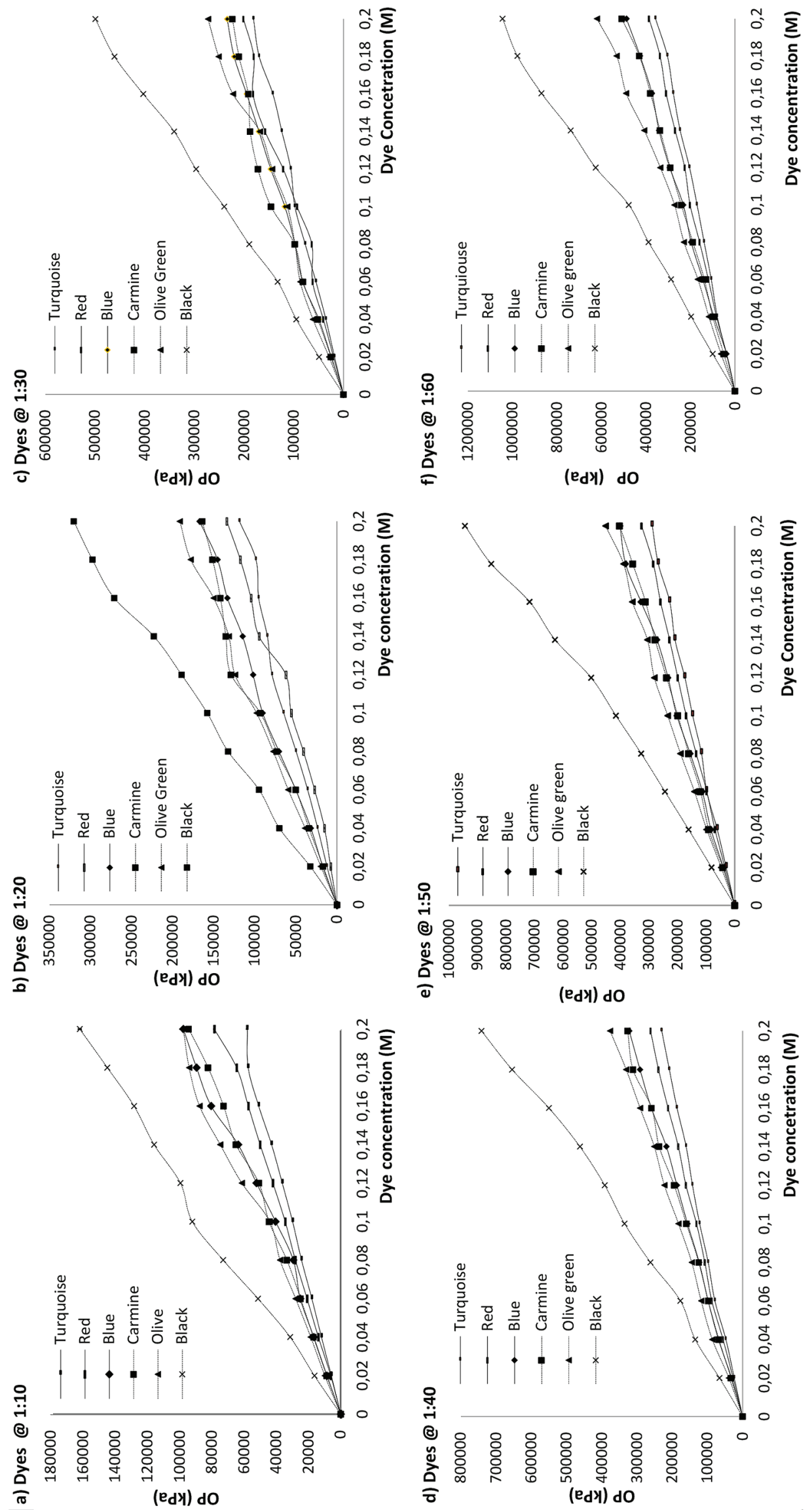
Based on Figs 2 and 3 it was concluded that the OP of the dyes at different concentrations and different dye-to-salt mass ratios is closely related to dye chemistry and $\mathrm{M}_{\mathrm{w}}$ rather than the type of dye (i.e reactive vs basic). This is further supported and demonstrated in the correlations seen in Fig. 4, which demonstrates the relationship between the $\mathrm{OP}$ and $\mathrm{M}_{\mathrm{w}}$. Figure 4 (a) demonstrates the relationship between OP and $\mathrm{M}_{\mathrm{w}}$ in the order Blue $(482 \mathrm{~g} / \mathrm{mol})>>$ Red $(402 \mathrm{~g} / \mathrm{mol})>$ Turquoise $(359 \mathrm{~g} / \mathrm{mol})$. Figure 4 (b) demonstrates the relationship between OP and $\mathrm{M}_{\mathrm{w}}$ in the order Black $(991 \mathrm{~g} / \mathrm{mol})>>$ Olive $(585 \mathrm{~g} / \mathrm{mol})$ $>$ Carmine $(492 \mathrm{~g} / \mathrm{mol})$.

As far as the authors could deteremine no other study has reported the OP of dye solutions as possible DS. The only other related studies are that of Han et al. (2016) which reported on the potential treatment of textile wastewater using FO, but did not report on the OP of the textile wastewater, and that of Zhao et al. (2015) that reported on using polyacrylamide as a draw solute to treat dye wastewater. Even in this study only the OP of the polyacrylamide and $\mathrm{KCl}$ were reported and not that of the dyes or dye wastewater. Further studies will be conducted to determine the type and number of dye species formed (refered to as the colligative properties of the solution), which is important because they contribute directly to the OP of the solution and will be reported in a subsequent article once that data is available.

\section{Dye as draw solute in forward osmosis experiment}

From the data presented, Reactive Black 5 was selected as the DS at an intital concentration of $0.02 \mathrm{M}$ with DI as a control FS. These experiments were conducted to evaluate dyes as a draw solute and were run until a pseudo steady-state was reached (i.e., no more water flux from the feed to the draw) to determine the maximum feed water recovery rate, while producing a target concentration dye solution $(0.004 \mathrm{M})$ that can be used directly in the dye-bath in the textile industry.

Figure 5 illustrates the OP of both feed and draw solutions over time. The initial OP gradient (i.e., driving force) was $16586 \mathrm{kPa}$. The OP for FS increased over time while that of the DS decreased over time. The increase in the OP of the DI was attributed to reverse solute flux of the dye, while the decrease in OP of the DS was due to water flux across the FO membrane (a) Basic dyes

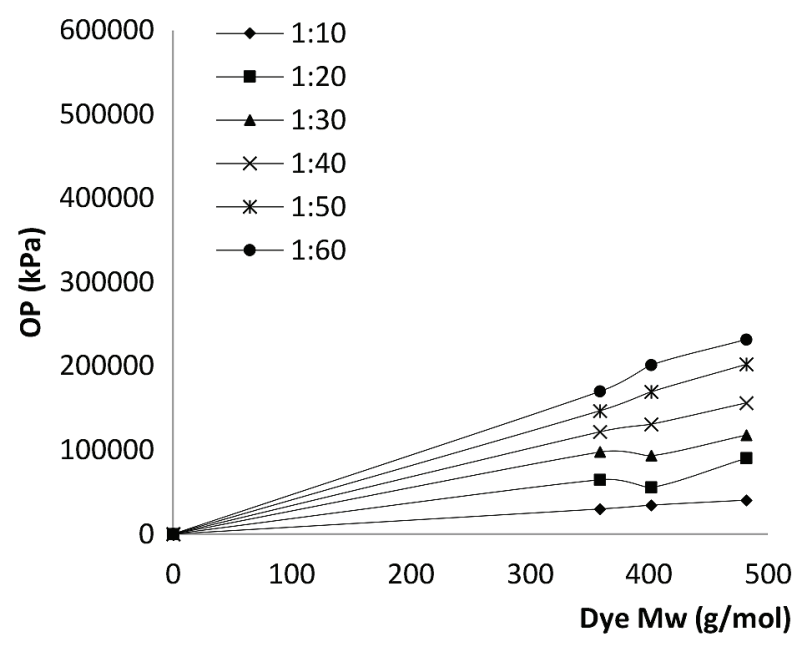

(b) Reactive dyes

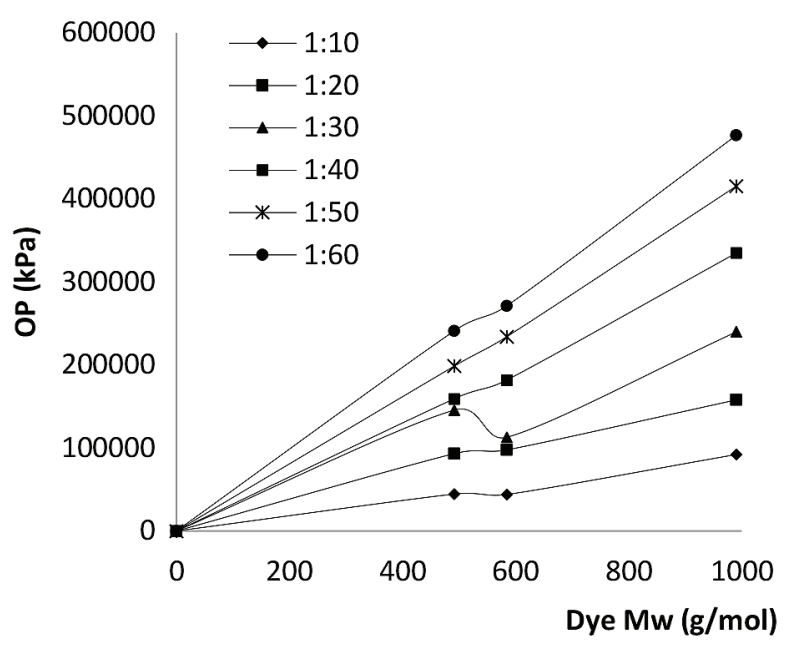

Figure 4

Correlation between osmotic pressure (OP) and molecular weight $\left(\mathrm{M}_{\mathrm{w}}\right)$ of (a) basic dyes and (b) reactive dyes at $0.1 \mathrm{M}$

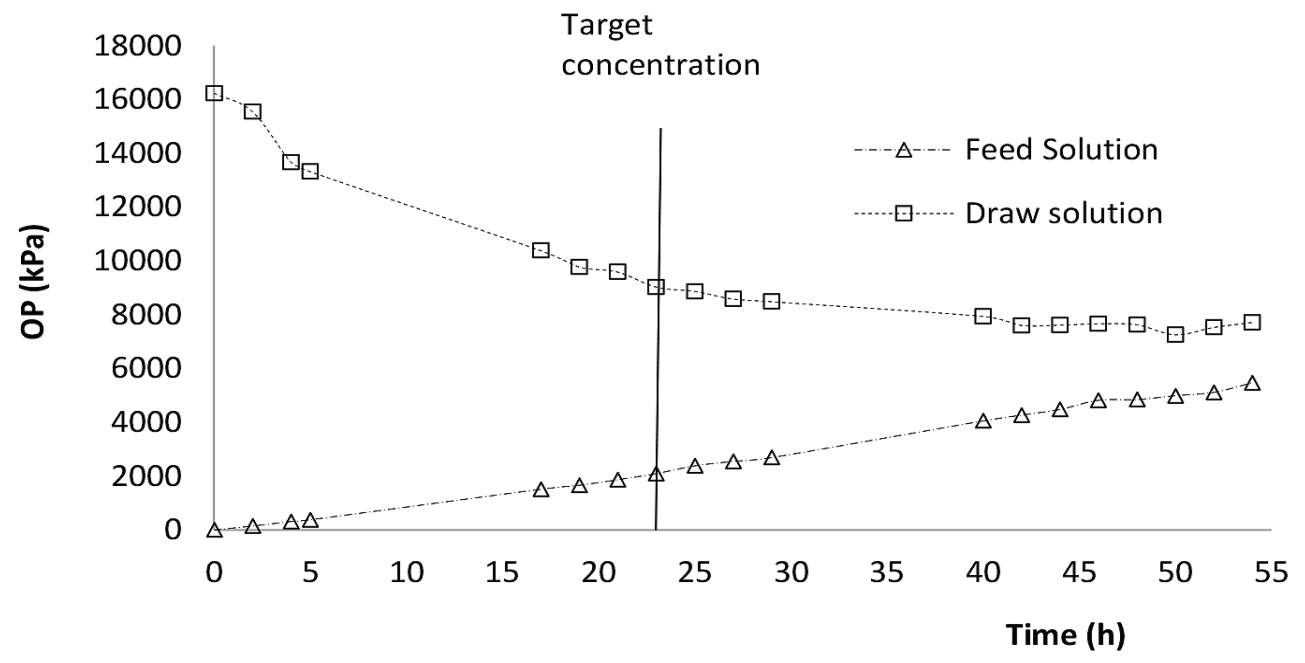

Figure 5

Osmotic pressure (OP) for DI as the control feed solution and Reactive Black 5 as draw solution at a dye-to-salt ratio of 1:10 
from the feed to the draw side, thereby diluting the DS. As shown in Fig. 5 the target concentration of $0.002 \mathrm{M}$ was reached after approximately $23 \mathrm{~h}$, corresponding to an OP of $8580 \mathrm{kPa}$. From observation there was no futher change in the volume of both the feed and draw solutions and no change in the weight of the feed after approximately $55 \mathrm{~h}$, where the final OP of the FS and DS was 5468 and $6667 \mathrm{kPa}$, respectively, with a feed water recovery rate of $60 \%$.

\section{CONCLUSIONS}

This study is part of a feasibility investigation on FO-based water saving in the textile industry. The results reported herein focus firstly on identifying and evaluating possible FSs and secondly evaluating and assessing basic and reactive dyes as potential and DSs.

The OP of the dyes with salt generated higher OP than the dyes without salt. The OP trends for the basic dyes followed Blue $>>$ Red $>$ Turquoise and for the reactive dyes Black $>>$ Olive $>$ Carmine, which is also the same order of the dyes' $\mathrm{M}_{\mathrm{w}}$. The overall $\mathrm{OP}$ trend was Black $>$ Olive $>$ Carmine $>$ Blue $>$ Red $>$ Turquoise. The trend for the OP for the different dyeto-salt ratios is 1:60 $>1: 50>1: 40>1: 30>1: 20>1: 10$. The OP generated by the basic and reactive dye solutions at different concentrations, up to $0.2 \mathrm{M}$, and different dye-to-salt mass ratios, up to $1: 60$, ranged from $160000 \mathrm{kPa}(160 \mathrm{~atm})$ to more than $1000000 \mathrm{kPa}(1000 \mathrm{~atm})$. It is concluded that the OP of the dyes at different concentrations and different dye-to-salt ratios is influenced more by the dye chemistry and $\mathrm{M}_{\mathrm{w}}$ than by the type of dye (i.e., reactive vs basic). For both the basic and reactive dyes a linear relationship exists between OP and dye concentration; as well as between OP and $\mathrm{M}_{\mathrm{w}}$. The dye DS exhibited greater OP than that of the FS evaluated, thus rendering them suitable draw solutions. Preliminary results demonstrated that Reactive Black 5 can used to extract water with a maximum recovery rate of $60 \%$ using DI water as the control.

Further studies will focus on the operation of the FO cell with the different dye solutions, as DS, against the alternative FS (brackishwater, seawater and textile wastewater). These studies will include an evaluation of the reclamation of water when TWW is used as the FS. It will also include an evaluation of whether dye solutions can be produced that can be used directly in the dyeing process, therefore eliminating the regeneration stage.

\section{ACKNOWLEDGEMENTS}

The work is based on the research supported wholly but the National Research Foundation (NRF) of South Africa. The grantholder acknowledges that opinions, findings and conclusions or recommendations expressed in this publication generated by the NRF-supported research is that of the author(s) and that the NRF accepts no liability whatsoever in this regard.

\section{REFERENCES}

ACHILLI A, CATH TY, MARCHAND EA and CHILDRESS AE (2009b) The forward osmosis membrane bioreactor: A low fouling alternative to MBR processes. Desalination 239 10-21. https://doi. org/10.1016/j.desal.2008.02.022

ACHILLI A, CATH TY and CHILDRESS AE (2010) Selection of inorganic-based draw solutions for forward osmosis applications. J. Membrane Sci. 364 (1-2) 233-241. https://doi.org/10.1016/j. memsci.2010.08.010
ALJEBOREE AM, ALSHIRIFI AN and ALKAIM AF (2017) Kinetics and equilibrium study for the adsorption of textile dyes on coconut shell activated carbon. Arab. J. Chem. 10 3381-3393. https://doi. org/10.1016/j.arabjc.2014.01.020

AKTHER N, SODIQ A, GIWA A, DAER S, ARAFAT HA and HASAN SW (2015) Recent advancements in forward osmosis desalination: A review. Chem. Eng. J. 281 502-522. https://doi.org/10.1016/j. cej.2015.05.080

BRAEKEVELT S, JØRGENSEN T, LAURITZEN K and HÉLIXNIELSEN C (2015) Challenges in commercializing biomimetic membranes. Membranes 5 (4) 685-701. https://doi.org/10.3390/ membranes5040685

CARTINELLA JL, CATH TY, FLYNN MT, MILLER GC, HUNTER KWJ and CHILDRESS AE (2006) Removal of natural steroid hormones from wastewater using membrane vontactor processes. Environ. Sci. Technol. 40 (23) 7381-7386. https://doi.org/10.1021/ es060550i

CATH TY, GORMLY S, BEAUDRY EG, FLYNN MT, ADAMS VD and CHILDRESS AE (2005) Membrane contractor processes for wastewater reclamation in space: Part I. Direct osmotic concentration as pretreatment for reverse osmosis. J. Membrane Sci. 257 (1-2) 85-98. https://doi.org/10.1016/j.memsci.2004.08.039

CATH TY, CHILDRESS AE and ELIMELECH M (2006) Forward osmosis: Principles, applications and recent developments: Review. J. Membrane Sci. 281 (1-2) 70-87. https://doi.org/10.1016/j. memsci.2006.05.048

ChemicalBook (2017) Carminic acid. ChemicalBook. URL: http:// www.chemicalbook.com/ChemicalProductProperty_EN CB1428489.htm (Accessed 10 April 2017).

CHOI Y-J, CHOI J-S, OH H-J, LEE S, YANG DR and KIM JH (2009) Toward a combined system of forward osmosis and reverse osmosis for seawater desalination. Desalination 247 (1-3) 239-246. https:// doi.org/10.1016/j.desal.2008.12.028

CHUNG TS, ZHANG S, WANG KY, SU J AND LING MM (2012). Forward osmosis processes: Yesterday, today and tomorrow. Desalination 287 78-81. https://doi.org/10.1016/j.desal.2010.12.019

COHEN-TANUGI D, MCGOVERN RK, DAVE SH, LIENHARD JH and GROSSMAN JC (2014). Quantifying the potential of ultrapermeable membranes for water desalination. Energ. Environ. Sci. 7 1134-1141. https://doi.org/10.1039/C3EE43221A

CORNELISSEN ER, HARMSEN D, DE KORTE KF, RUIKEN CJ, QIN J-J, OO H and WESSELS LP (2008) Membrane fouling and process performance of forward osmosis membranes on activated sludge. J. Membrane Sci. 319 (1-2) 158-168. https://doi.org/10.1016/j. memsci.2008.03.048

DOGAN M, TURHA Y, ALKAN M, NAMLI H, TURAN P and DEMIRBAS O (2008) Functionalized sepiolite for heavy metals ions adsorption. Desalination 230 (1-3) 248-268. https://doi. org/10.1016/j.desal.2007.11.029

EL-SAYED GO, AWAD MS and AYAD ZA (2014) Electrochemical decolorization of Maxilon Red GRL textile dye. Int. Res. J. Pure Appl. Chem. 4 (4) 402-416.

FIORAMONTI L (2015) Water shortages about to put load-shedding in the dark. Business Day 5 May 2015 URL: https://www.businesslive. co.za/bd/opinion/2015-05-05-water-shortages-about-to-put-loadshedding-in-the-dark/ (Accessed 8 December 2016).

GARCIA-CASTELLO EM, MCCUTCHEON JR and ELIMELECH M (2009) Performance evaluation of sucrose concentration using forward osmosis. J. Membrane Sci. 338 (1-2) 61-66. https://doi. org/10.1016/j.memsci.2009.04.011

GE Q, LING M and CHUNG T-S (2013) Draw solutions for forward osmosis processes: Developments, challenges, and prospects for the future. J. Membrane Sci. 442 225-237. https://doi.org/10.1016/j. memsci.2013.03.046

GETHARD K, SAE-KHOW O AND MITRA S (2011) Water desalination using carbon-nanotube-enhanced membrane distillation, ACS. Appl. Mater. Interfaces 3 (2) 110-114. https://doi. org/10.1021/am100981s

HAN G, LIANG C-Z, CHUNG T-S, WEBER M, STAUDT C 
and MALETZKO C (2016) Combination of forward osmosis (FO) process with coagulation/flocculation (CF) for potential treatment of textile wastewater. Water Res. 91 361-370. https:/doi. org/10.1016/j.watres.2016.01.031

HEY T, BAJRAJTARI N, VOGEL J, HELIX-NIELSEN C, LA COUR JANSEN J and JÖNSSON J (2016a). The effects of physicochemical pre-treatment of municipal wastewater on forward osmosis. Environ. Technol. 38 (17) 2130-2142. https://doi.org/10.1080/09593 330.2016 .1246616

HEY T, ZAREBSKA A, BAJRAKTARI N, VOGEL J, HÉLIX-NIELSEN C, LA COUR JANSEN J and JÖNSSON K (2016b) Influences of mechanical pre-treatment on the non-biological treatment of municipal wastewater by forward osmosis. Environ. Technol. 38 (18) 2295-2304. https://doi.org/10.1080/09593330.2016.1256440

HEY T, BAJRAKTARI N, DAVIDSSON A, VOGEL J, HÉLIXNIELSEN C, LA COUR JANSEN J and JÖNSSON K (2017) Evaluation of direct membrane filtration and direct forward osmosis as concepts for compact and energy positive municipal wastewater treatment. Environ. Technol. 39 (3) 264-276.

HOUSHYAR S and AMIRSHAHI SH (2002) Treatment of cotton with chitosan and its effect on dyeability with reactive dyes. Iranian Polym. J. 11 (5) 295-301.

JUNG EK (2013) A pilot scale fertiliser drawn forward osmosis and nanofiltration hybrid system for desalination. Unpublished thesis, School of Civil and Environmental Engineering, Faculty of Engineering and Information Technology, University of Technology, Sydney (UTS), New South Wales, Australia.

KLAYSOM C, CATH TY, DEPUYDTA T and VANKELECOM IFJ (2013) Forward and pressure retarded osmosis: Potential solutions for global challenges in energy and water supply. R. Soc. Chem. 42 6959-6989. https://doi.org/10.1039/c3cs60051c

KORENAK J, BASU S, BALAKRISHNAN M, HELIX-NIELSEN C and PETRINIC I (2017) Forward osmosis in water treatment processes. Acta Chim. Slovenica 64 83-94. https://doi.org/10.17344/ acsi.2016.2852

LAY WCL, CHONG TH, TANG CY, FANE AG, ZHANG J and LIU Y (2010) Fouling propensity of forward osmosis: investigation of the slower flux decline phenomenon. Water Sci. Technol. 61 (4) 927-936. https://doi.org/10.2166/wst.2010.835

LANGE O, NOBEL P, OSMOND C and ZIEGLER H (1983) Physiological Plant Ecology (III) Response to the Chemical and Biological Environment. Springer Verlag, Berlin, Heidelberg.

MCCUTCHEON JR, MCGINNIS RL and ELIMELECH M (2005) A novel ammonia-carbon dioxide forward (direct) osmosis desalination process. Desalination 174 1-11. https://doi. org/10.1016/j.desal.2004.11.002

MCCUTCHEON JR and ELIMELECH M (2006) Influence of concentrative and dilutive internal concentration polarization on flux behavior in forward osmosis. J. Membrane Sci. 284 (1-2) 237-247. https://doi.org/10.1016/j.memsci.2006.07.049

MCGINNIES RL and ELIMELECH M (2007) Energy requirements of ammonia-carbon dioxide forward osmosis desalination. Desalination 207 (1-3) 370-382. https://doi.org/10.1016/j. desal.2006.08.012

MCGINNIES RL and ELIMELECH M (2008) Global challenges in energy and water supply: the promise of engineered osmosis. Environ. Sci. Technol. 42 (23) 8625-8629. https://doi.org/10.1021/ es $800812 \mathrm{~m}$

MCGOVERN RK (2014) The economics of future membrane desalination processes and applications. Unpublished $\mathrm{PhD}$ thesis, Massachusetts Institute of Technology, USA.

MI B and ELIMELECH M (2010) Organic fouling of forward osmosis membranes: fouling reversibility and cleaning without chemical reagents. J. Membrane Sci. 348 (1-2) 337-345. https://doi. org/10.1016/j.memsci.2009.11.021

PHUNTSHO S, SHON HK, HONG S, LEE S and VIGNESWARAN $S$ (2011) A novel low energy fertiliser driven forward osmosis desalination for direct fertigation: Evaluating the performance of fertiliser draw solutions. J. Membrane Sci. 375 172-181. https://doi. org/10.1016/j.memsci.2011.03.038

PHUNTSHO S (2012) A novel fertiliser drawn forward osmosis desalination for fertigation. Unpublished $\mathrm{PhD}$ thesis, School of Civil and Environmental Engineering, University of Technology Sydney (UTS), Australia.

PHUNTSHO S, SHON HK, HONG S, LEE S, VIGESWARA S and KANDASABY J (2012) Fertiliser drawn forward osmosis desalination: The concept, performance and limitations for fertigation. Rev. Environ. Sci. Biotechnol. 11 147-168. https://doi. org/10.1007/s11157-011-9259-2

PHUNTSHO S, LOTFI F, HONG S, SHAFFER DL, ELIMELECH $\mathrm{M}$ and SHON HK (2014) Membrane scaling and flux decline during fertiliser-drawn forward osmosis desalination of brackish groundwater. Water Res. 57 172-182. https://doi.org/10.1016/j. watres.2014.03.034

RAHMAN BHUIYAH MA, SHAID A and KHAN MA (2014) Cationization of cotton fiber by chitosan and its dyeing with reactive dye without salt. Chem. Mater. Eng. 2 (4) 96-100.

SABNIS RW (2010) Handbook of Biological Dyes and Stains. John Wiley and Sons, New Jersey. https://doi.org/10.1002/9780470586242

SEMIAT R (2008) Energy issues in desalination processes. Environ. Sci. Technol. 42 (22) 8193-8201.

SHAFFER DL, WERBER JR, JARAMILLO H, LIN S and ELIMELECH M (2015) Forward osmosis: Where are we now? Desalination 356 271-284. https://doi.org/10.1016/j.desal.2014.10.031

SHANNON MA, BOHN PW, ELIMELECH M, GEORGIADIS JG, MARINAS BJ and MAYES AM (2008) Science and technology for water purification in the coming decades. Nature 452 (7185) 301-310. https://doi.org/10.1038/nature06599

SING N, PETRINIC I, HELIX-NIELSEN C, BASU S and BALAKRISHMAN M (2018) Concentrating molasses distillery wastewater using biomimetic forward osmosis (FO) membranes. Water Res. 130 271-280. https://doi.org/10.1016/j. watres.2017.12.006

SCHNORR JM and SWAGER TM (2011) Emerging applications of carbon nanotubes. Chem. Mater. 23 (3) 646-657. https://doi. org/10.1021/cm102406h

TANG CY, SHE Q, LAY WCL, WANG R and FANE G (2010) Coupled effects of internal concentration polarisation and fouling on flux behaviour of forward osmosis membranes during humic acid filtration. J. Membrane Sci. 354 (1-2) 123-133. https://doi. org/10.1016/j.memsci.2010.02.059

TANG C, WANG Z, PETRINIC I, FANE AG and HÉLIX-NIELSEN $\mathrm{C}$ (2015) Biomimetic aquaporin membranes coming of age. Desalination 368 89-105. https://doi.org/10.1016/j.desal.2015.04.026

TRUETT LJ and TRUETT DB (2010) New challenges for the South African textile and apparel industries in the global economy. $J$ Econ. Dev. 35 (4) 73-91.

VON BORMANN T and GULATI M (2014) The food energy water nexus: Understanding South Africa's most urgent sustainability challenge. WWF-SA, South Africa. 1-35.

WANG KY, ONG RC and CHUNG TS (2010) Doubled-skinned forward osmosis membranes for reducing internal concentration polarization within porous sublayer. Ind. Eng. Chem. Res. 49 4824-4831. https://doi.org/10.1021/ie901592d

WANG R, SETIAWAN L and FANE AG (2012) Forward osmosis: Current status and perspectives. J. Membrane Sci. 281 70-87.

WICAKSANA F, FANE AG, TANG C and WANG R (2012) Nature meets technology: forward osmosis membrane technology. In: Hélix-Nielsen C (ed.) Biomimetic Membranes for Sensor and Separation Applications. Springer, Dordrecht. 21-42.

WIJAYASIRI L and MCCOMBE K (2016) The Primary FRCA Structure Oral Exam Guide 1 ( $\left.2^{\text {nd }} e d n\right)$. CRC Press, London.

YANG Q, WANG KY and CHUNG TS (2009) A novel duallayer forward osmosis membrane for protein enrichment and concentration. Sep. Purif. Technol. 69 269-274. https://doi. org/10.1016/j.seppur.2009.08.002

YIP NY, TIRAFERRI A, PHILLIP WA, SCHIFFMAN JD and ELIMELECH M (2010) High performance thin-film composite

http://dx.doi.org/10.4314/wsa.v44i2.11

Available on website http://www.wrc.org.za

ISSN 1816-7950 (Online) = Water SA Vol. 44 No. 2 April 2018

Published under a Creative Commons Attribution Licence 
forward osmosis membrane. Environ. Sci. Technol. 44 (10) $3812-$ 3818. https://doi.org/10.1021/es1002555

ZHANG S and YANG J (2003) Current Trends in dye chemistry and dyeing technology [J]. Dyestuff Dyeing 40 (4) 185-188.

ZHAO S, ZOU L, TANG CY and MULCAHY D (2012a). Recent developments in forward osmosis: Opportunities and challenges. J. Membrane Sci. 396 1-21. https://doi.org/10.1016/j.memsci.2011.12.023

ZHAO Y, QIU C, LI X, VARARATTANAVECH A, LI X, SHEN W, TORRES J, HÉLIX-NIELSEN C, RONG W, HU X, FANE AG and TANG CY (2012b) Synthesis of robust and highperformance aquaporin based biomimetic membrane by Interfacial polymerization-membrane preparation and RO performance Characterization. J. Membrane Sci. 423-424 422-428. https://doi. org/10.1016/j.memsci.2012.08.039

ZHAO C, XUE J, RAN F and SUN S (2013) Modification of polyethersulfone membranes: A review of methods. Prog. Mater. Sci. 58 76-150. https://doi.org/10.1016/j.pmatsci.2012.07.002 ZHAO P, GAO B, XU S, KONG J, MA D, SHON HK, YUE Q, and LUI P (2015) Polyelectrolyte-promoted forward osmosis process for dye wastewater treatment - Exploring the feasibility of using polyacrylamide as draw solute. Chem. Eng. J. 264 32-38. https://doi. org/10.1016/j.cej.2014.11.064 